\title{
RIGHTS OF PERSONS WITH DISABILITIES IN NIGERIA
}

\author{
Edwin Etieyibo \\ Department of Philosophy, University of the Witwatersrand, Johannesburg, South Africa \\ This paper employs the conceptual-analytical method to analyse literature and news reports on \\ disabilities, and international legal documents and instruments on human rights and the rights of \\ persons with disabilities to which Nigeria is a signatory. This study is conducted in the context of \\ exclusionary and discriminatory practices against persons with disabilities in Nigeria. The practices \\ and rights that are examined are in the areas of education and accessibility with regard to adults \\ and children with disabilities, work and employment, and the employment or use of children with \\ disabilities in alms-soliciting. The paper's broad objective in critically discussing these practices is to \\ make a case for why and how they violate the rights of persons with disabilities.
}

KEY WORDS: DISCRIMINATORY PRACTICES, DISABILITY, HUMAN RIGHTS, NIGERIA, PERSONS WITH DISABILITIES, RIGHTS

\section{Introduction}

The general focus of this paper is on certain exclusionary and discriminatory practices against persons with disabilities in Nigeria in connection with legal rights documents and instruments. More specifically, the paper critically discusses these practices in four broad areas. First, in the area of education (as it affects persons - adults and children - with disabilities). Second, in the employment or use of children with disabilities to beg for alms. Third, in the area of safety and accessibility (as it affects persons with disabilities). Fourth, in work and employment (as it relates to adults with disabilities). In addition to discussing these practices, the paper examines how they constitute violations of the rights of persons with disabilities.

Children are human beings in their own right so one may ask the following questions: Why are we separating "persons with disabilities" from "children with disabilities"? Why do we not rather use the expression "children with disabilities" and "adults with disabilities" rather than "persons with disabilities?" These are important and legitimate questions. Given that children with disabilities also fall under the category of persons with disabilities, the exclusionary and discriminatory practices that will be discussed in the paper in respect of the violation of the rights of persons with disabilities will also apply to children with disabilities. Consequently, when both categories (adults and children with disabilities) are referred to in the paper, the broad term 'persons with disabilities' will be used. Nevertheless, given that there are certain exclusionary and discriminatory practices that are directed at or directly perpetuated against children with disabilities (in virtue of 
their being children with disabilities) it seems only proper to examine the violations of the rights of children with disabilities separately. Furthermore, many international and national legal instruments do recognise separately the rights of children with disabilities even though there exist legal instruments that recognise the rights of persons with disabilities (see Nigeria, I999a; Nigeria, I999b; Nigeria, 2009/20II/20I6; United Nations, I948; United Nations, I966a; United Nations, I966b; United Nations, I989; United Nations, 2006a; United Nations, 2006b).

In examining the exclusionary and discriminatory practices against persons with disabilities in Nigeria, we shall use a conceptual-analytical methodology. That is, the paper will not be engaging in empirical research or providing an analysis of some qualitative studies on the exclusionary and discriminatory practices against persons with disabilities. Rather, using the method of conceptual analysis (which is about the analysis of concepts with a view to drawing out connections amongst them in the context of various issues), the paper will be drawing on local newspaper articles, and some previous research on disability in Nigeria to evaluate the practices that violate the rights of adults and children with disabilities in Nigeria. Because the conceptual-analytical methodology is used in this paper, no interviews were conducted. However, reference is made to a small number of studies, and other research and newspaper articles that conducted interviews. The ideas and views of the individuals in these interviews are discussed in the paper to advance the general claim and argument of the paper. There are two criteria that determined the use of sources in this paper. First, literature and articles were selected on the basis of their relevance to the issues around disabilities being discussed. Second, given the paucity of literature on disability in Nigeria, the paper is limited to making use of sources other than research or published work on disability. This explains, to an extent, the substantial use of a number of newspaper articles in order to try to present incidences of disabilities as well as social perceptions of disabilities.

This conceptual-analytical exploration is important as it helps to bring out certain ideas related to disabilities, rights and discriminatory practices, and which in turn further the notion of the correctness of the social model of disability, the model that is now widely accepted in the disability literature. For, if the thesis that the rights of adults and children with disabilities in Nigeria are violated by certain exclusionary and discriminatory practices is correct, then it is the case that their disabilities cannot be understood outside the social practices that discriminate against them or perpetuate certain beliefs about disability. In the social model of disability (which contrasts with the medical model of disability), disability is understood in the context of oppression and arises due to the failure of society (social environment and structure) to adapt to the needs and aspirations of people with disabilities. So, even though this paper is not presenting the results of an original, empirical research there is reason to think that its conceptual-analytical discussion of disabilities, rights and discriminatory practices is important, not least for the following reasons: (I) it lends weight to the social model of disability; (2) it opens up space for rigorous discussions of these issues, and (3) it motivates further original empirical research on these and other exclusionary and discriminatory practices. 


\section{Notions of disability: social and medical models of disability}

Above, the social and medical models of disability have been mentioned. This section takes the discussion further by providing an overview of both models, trying to pin down various notions of disability. This discussion is given in order to properly provide a context for the discussion of disability issues in Nigeria.

Persons with disabilities are some of the world's largest minorities. History has shown that they have not always been treated fairly and equally. Historical examples of discrimination against people with different forms of physical and mental disabilities range from being ridiculed to being condemned to permanent exclusion in asylums; from being allowed to drown or die to being outrightly executed (Pritchard, 1963). As Barton (1993) noted, throughout antiquity people with disabilities have been subjected to a multitude of oppressive social attitudes, which have included "horror, fear, anxiety, hostility, distrust, pity, over-protection and patronizing behavior". The real issue as far as disability is concerned, therefore, has to do with these pejorative attitudes combined with, according to Barnes (I99I), particular social contexts, namely, the way people with disabilities are treated and an inhospitable physical environment (i.e. inaccessible buildings and unusable transport systems, etc.).

Terms such as 'pejorative attitudes' and 'particular social contexts' vis-a-vis disability suggest a particular notion of disability, i.e. the social model of disability, which arose in response to the medical model of disability. This is the model (social model of disability) that will be adopted in this paper. Discussions on disability have in the last 30 years moved away from the medical model of disability to the social model of disability. On the former approach, the notion of disability is understood as a medical condition involving physical features of individuals. This is the sort of model expressed in the definition of disability in The Disability and Discrimination Act (United Kingdom, 1995), which takes a person with disability as someone who "has a physical or mental impairment that has a substantial and long-term adverse effect on his or her ability to carry out normal day-to-day activities." By contrast, to the medical model of disability, the social model of disability gives primacy and importance to certain social contexts such as politics, empowerment, citizenship and choice in the expression of disability. Disability is construed in terms of society's failure to provide adequate and appropriate services for its citizens. This is the model we see expressed by the World Health Organization (WHO), which takes disability as an "umbrella term, covering impairments, activity limitations, and participation restrictions" (20II; see also WHO, n.d.; WHO, 20I8a and WHO, 2018b). This model of disability understands the concept as not just a health problem, but sees it as a complex phenomenon, reflecting the interaction between features of a person's body and characteristics of the society or environment in which he or she lives. That is to say, disability does not simply refer to an individual's intrinsic features but comes about as "a result of an interaction between a person (with a health condition) and that person's contextual factors (both environmental and personal factors)" (WHO, 20II) and as "mainly as a socially created problem, and basically as a matter of the full integration of individuals into society" (WHO, 2018a).

The social model of disability has evolved substantively over the last three decades. 
Having said that the social model of disability takes contextual factors into account in its understanding of disability it is important to point out that this model is not a monolithic entity. Rather, from the literature analysis below it can be seen as consisting of a cluster of approaches to the understanding of the notion of disablement revolving around the role that a person's contextual factors play in understanding notions of disability.

In exploring the notion of the social model of disability, Hahn (I986) takes disability as "the failure of a structured social environment to adjust to the needs and aspirations of citizens with disabilities rather than from the inability of the disabled individual to adapt to the demands of society". As for Charlton (I998), disability should be understood within the context of oppression. He notes that the majority of people with disability have been so psychologically oppressed by society that their oppression has become internalised, leading to them developing, what he calls a Marxian notion of "false consciousness", according to which they now come to believe that they are less capable than others. The theme of social oppression as it applies to people with disabilities also features in the work of Abberley (1987). He argues that analogous to other groups in society (i.e. women and ethnic minorities), people with disabilities encounter oppression, whereby such oppression in turn gives rise to institutional discrimination. Like Charlton (I998), Oliver (I990) analyses a variant of the social model of disability in his seminal work The Politics of Disablement. In this work, he seeks to provide conclusive evidence that disability "as a category can only be understood within a framework which suggests that it is culturally produced and socially structured".

The disability movement has effectively utilised the social model of disability both as a (i) political platform and (ii) tool to secure the "rights" of people with disabilities. Besides exploiting this model of disability to advance and secure the "rights" of people with disabilities with a view to ensuring that they enjoy the status of full and equal citizenship in society, the disability movement has also taken advantage of the emergence of several legal provisions in international conventions (or treaties and laws) that have variously recognised the rights of persons with disabilities. A clear example of how the disability movement has used the social model of disability is in the context of disability discourse in the US (for historical timelines re developments in disability perspectives with specific reference to the US, see Teaching for Diversity and Social Justice, 2007).

One quick and subtle conclusion that can be drawn from the foregoing is that the disability movement and the various legal provisions in international conventions recognising the rights of persons with disabilities in recent decades are significant points in the advancement of the rights of people with disabilities. Notwithstanding this advancement, persons with disabilities are still treated unfairly and unequally in many societies. This is particularly the case in Nigeria where they are still widely discriminated against in the areas of education, employment, sports, religion and social life (see BabaOchankpa, 20Io). This continuous discrimination against people with disabilities in Nigeria is the context for this paper. 


\section{Human rights discourse}

Since the central thesis of this paper concerns rights, an examination of the notion of rights or human rights will seem to be apposite. There are several descriptions or characterisations of human rights that have been put forward by scholars. One such description takes human rights as representing demands or claims which individuals or groups make on society, some of which are protected by law and have become part of some lofty ideals, while others remain aspiration to be attained in the future (Eze I984). Another characterisation - an idealistic and limited view of human rights - has been put forward by Cranston (I980). He describes human rights as supremely sacred, as "something which no one may be deprived of without a great affront to justice". There is a third characterisation of human rights that we should consider, one that is put forward by Nickel (I987), according to which rights are construed as "basic moral guarantees that persons in all countries and cultures allegedly have simply because they are persons." Calling these guarantees 'rights', according to him, "suggests that they attach to particular individuals who can invoke them, that they are of high priority, that compliance with them is mandatory rather than discretionary", and that they "exist and are available as standards of justification and criticism whether or not they are recognized and implemented by the legal system or officials of a country".

The latter author's characterisation of human rights suggests that human rights are something inherent to humans. This description makes it right then to see the target of human rights to be the humanity in every human, that is what makes us distinctively human minus the various contingencies of race, sex and gender, characteristics and abilities. This view of human rights as tied to the humanity in us implies two things about human rights. Firstly, that they are expressions of the principle of equality, where this principle is construed as a prescriptive norm, which takes all humans to possess equal moral and legal standing irrespective of differences in racial, gender, socio-economic status, physical and mental abilities. Secondly, that human rights are inherent in our nature, without which we cannot live or flourish as human beings.

In conclusion, we might say that the characterisation of human rights as being inherent to human beings is a comprehensive doctrine of human rights insofar as the claim rests upon a particular fundamental philosophical claim, namely, moral universalism and the belief in the existence of a truly universal moral community comprising all human beings. That is, the view that "there exists a rationally identifiable moral order, an order whose legitimacy precedes contingent social and historical conditions and applies to all human beings everywhere and at all times" (Fagan, 20I0). The point therefore is that human rights are inherent to humans. They arise from the very nature of humans as endsin-themselves, i.e. beings that are valuable in and of themselves and not mere objects that could be manipulated by others for their desired ends. The deprivation of such rights robs humans of dignity and constitutes a great affront to our universal, collective and natural sense of justice (Ajomo \& Olasaneye, I993). 


\section{Legal frameworks and instruments on rights}

We will now consider some of the legal frameworks and instruments that outline the rights of persons with disabilities. Above, it was suggested that one of the significant points in the advancement of the rights of people with disabilities is the emergence, in the last two decades, of various legal provisions in international conventions recognising the rights of persons with disabilities. In looking at these legal frameworks and instruments, we will first consider international (United Nations) legal documents and instruments (in the section below) and some local (Nigeria's) legal instruments and documents (in the section following the International (United Nations) legal instruments and documents).

\section{International (United Nations) legal instruments and documents}

Some of the legal instruments and documents that will be examined in this section are the Convention on the Rights of Persons with Disabilities 2006a (CRPD), the International Convention on Civil and Political Rights I966a (ICCPR), the International Covenant on Economic, Social and Cultural Rights I966b (ICESCR), and the Convention on the Rights of the Child rg89 (CRC).

Human rights are recognised and protected by a number of international human rights instruments (treaties, laws and conventions, etc.) such as the Universal Declaration of Human Rights (United Nations, I948), the ICCPR and ICESCR - documents that are generally referred to as the International Bill of Rights. Rights of persons with disabilities are recognised and protected by the CRPD, which enjoins state parties to "take appropriate measures, including legislation to modify or abolish existing laws, regulations, customs and practices that constitute discrimination against" persons with disabilities (CRPD, article 4). The CRPD and its "Optional Protocol" was adopted on I3 December 2006 at the United Nations Headquarters in New York and entered into force on 3 May 2008. As a key international instrument on the rights of persons with disabilities, it is the first comprehensive human rights treaty of the 2Ist century (United Nations, Convention and Optional Protocol Signatures and Ratifications, 2006b). With regard to children, the CRC makes provisions that protect the right of the child. This document sets the standard for how children should be treated around the world. By extension, it recognises and protects the rights of children with disabilities. Nigeria is a state party and signatory to all of these legal instruments and by implication is bound to follow through on all of their provisions.

We can say that the rights of persons with disabilities fall within the general category of human rights, even though we may speak of rights that are specific to them, or develop and formulate legal instruments that apply only to them. On this understanding, the reference to all humans as contained in the ICCPR and ICESCR likewise applies to persons with disabilities given that, in general, they enjoin states parties to respect the rights (civil, political, economic social and cultural) of all humans.

In the main, the ICCPR and ICESCR are concerned with general human rights. They take into account rights that are inherent to all human beings, irrespective of race, ethnicity, nationality, sex, religion, language, or any other status. On its part, the CRPD picks out rights that are particular to persons with disabilities. Part of the importance of recognising 
these specific rights is so as to offer persons with disabilities more protection and to include, rehabilitate and integrate them more fully into society.

The CRPD adopts a very broad categorisation of persons with disabilities, which focuses on the affirmation of all types of disabilities, and the full and equal enjoyment of all human rights and fundamental freedoms for those with disabilities. In addition, it affirms the promotion and respect for the inherent dignity of persons with disabilities and enjoins states parties to promote and protect their rights as a way of ensuring that they enjoy full equality under the law. There are eight guiding principles that underlie the Convention (CRPD). These are: (a) respect for inherent dignity, individual autonomy including the freedom to make one's own choices, and independence of persons; (b) non-discrimination; (c) full and effective participation and inclusion in society; (d) respect for difference, and acceptance of persons with disabilities as part of human diversity and humanity; (e) equality of opportunity; (f) accessibility; (g) equality between men and women; (h) respect for the evolving capacities of children with disabilities, and respect for the right of children with disabilities to preserve their identities (article 3 ). The principles and provisions in the CRPD are mutually reinforced by the substantive rights of persons with disabilities that it recognises. Some of these rights are also affirmed in the ICCPR and ICESCR. Some of the rights that are affirmed in the CRPD and ICCPR include the following: the right to "life" (CRPD article Io; ICCPR article 6); the right to the enjoyment of "liberty and security of person" (CRPD article I4; ICCPR article 9 ); the right to liberty of movement, nationality or residence (CRPD article I8; ICCPR article I2); and the right to "privacy" (CRPD article 22; ICCPR article I7). The right to "education" is one right that is affirmed by both the CRPD and ICESCR (CRPD article 24; ICESCR article I3). In general, many of the rights contained in the CRPD are affirmed by the ICCPR and ICESCR insofar as they are rights that broadly deal with aspects of the physical and mental integrity of persons qua persons. So, for example, many of the civil and political rights in the ICCPR are also affirmed in the CRPD in respect of persons with disabilities, and a number of the economic, social and cultural political rights in the ICESCR are recognised in the CRPD with regard to persons with disabilities.

However, there are certain rights that are specific to the CRPD, and these include the rights to "accessibility including information technology" (article 9), "live independently and be included in the community" (article I9), "personal mobility" (article 20), "habilitation and rehabilitation" (article 26), and "adequate standard of living and protection" (article 28). Furthermore, the CRPD enjoins states parties to raise awareness of the rights of persons with disabilities (article 8), to "adopt all appropriate legislative, administrative and other measures for the implementation of the rights recognised in the convention", and take "appropriate measures, including legislation, to modify or abolish existing laws, regulations, customs and practices that constitute discrimination against persons with disabilities" (article 4).

With regard to children, the CRC is notable for being the first binding instrument in international law to deal comprehensively with the rights of children, and also for including an article with regard to the rights of children with disabilities. Article 23 outlines a number of provisions, which recognise that a child with mental or physical 
disabilities is entitled to enjoy a full and decent life, in conditions that ensure dignity, promote self-reliance and facilitate the child's active participation in the community. In addition to outlining these provisions, article 23 also spells out the obligations of states parties to implement these provisions. Further to this general provision, in article 23 there are specific provisions in the CRC on the child's rights that relate to the point that will be made later on about alms-soliciting and children with disabilities. Article 28 concerns the child's right to free and compulsory primary education, to secondary and vocational education and the prevention of drop out; article 32 relates to the protection of the child from work that interferes with education.

\section{Nigeria's legal instruments and documents}

Two of the prominent legal instruments in Nigeria that will be considered are the Constitution of the Federal Republic of Nigeria I999a (henceforth, Nigerian Constitution), and the Nigerian Discrimination Against Persons with Disabilities (Prohibition) Act (2009, 20II and 20I6). Hereinafter, this Act will simply be referred to as the Disabilities Act The Nigerian Constitution (I999a) also recognises some similar rights as those in the ICCPR and ICESCR. It aims to "maintain and enhance the human dignity of all persons" (chapter II, section I(2)). That is, it recognises the human and equal rights of every citizen, and the "sanctity of the human person" (Nigerian Constitution: chapter IV sections 3335, $37 \& 4 \mathrm{I}-42$ ). Explicit provisions in respect of the rights of citizens can be found in chapter IV. Section 33(I) states that "every person has a right to life, and no one shall be deprived intentionally of his life, save in execution of the sentence of a court in respect of a criminal offence of which he has been found guilty in Nigeria". Section 34(I) stipulates that "every individual is entitled to respect for the dignity of his person" and section 35(I) states that with the exception of certain circumstances in accordance with procedure permitted by law "every person shall be entitled to his personal liberty."

If one applies the above provisions (in the Nigerian Constitution) broadly, then they can be said to similarly apply to persons with disabilities. However, the absence of a clear, specific, and robust reference to the rights of persons with disabilities in the Nigerian Constitution necessitated the upper legislative arm of the Nigerian Government (The Senate) to enact the Disabilities Act, of which a few things need to be said as a preamble. The passage into law of the Disabilities Act has been protracted and it has its different versions. The Disabilities Act was first passed into law on Io March 2009 by the Nigerian Senate. But it did not get the assent of the then President of Nigeria, Umaru Yar'Adua. In $201 \mathrm{I}$ and 20I4, the Act was again passed by the Senate and in both occasions, it was not assented to by President Goodluck Ebele Jonathan. Only recently (I3 July 2016), it was passed by the Senate but still yet to be signed into law by President Muhammadu Buhari. There are not many variations amongst the versions of the 2009, 20II, 20I4 and 2016 Act. The only noticeable difference is that the 20II, 2014 and 2016 versions establish a National Commission to oversee and monitor the implementation of provisions in the Act as well as formulate and implement policies and guidelines as appropriate with regard to the education and social development of persons with disability. 
In general, the Disabilities Act is meant to provide the framework for the full integration of people with disabilities into Nigerian society and to ensure that their rights (social and economic rights including the rights to education and healthcare) as contained in the Nigerian Constitution are attained and realised. The Disabilities Act applies to persons with disabilities who are citizens or legal immigrants of Nigeria and seeks to protect and enhance the rights of persons with disabilities in all areas of social, economic, cultural and political life. It forbids actions by any person or institution that discriminate against persons with disabilities on account of their disability (section I). Some of the provisions in the Act in the areas of life, liberty and security of person, education, work and employment, accommodation, safety and accessibility are similar to those in the CRPD. The rights that will be considered going forward are in education, work and employment, accommodation, safety and accessibility.

In terms of education, section 56 ( $\mathrm{I}$ and 2 ) states that a person with disability shall have a right to education without discrimination or segregation in any form, and is entitled to free education at all levels in all public educational institutions. In addition, section 57(I) requires that all schools shall be inclusive of and accessible to persons with disabilities and "shall have (a) at least one trained staff member to cater for the educational development of persons with disabilities; (b) a program for continued training of personnel catering for persons with disabilities; (c) special facilities for the effective education of persons with disabilities."

In terms of work and employment, section 67 states that "persons with disabilities shall have the right to work, on an equal basis with others" and "the right to opportunity to gain a living by work freely chosen or accepted in a labour market." Section 68(I) prohibits employers from dismissing any person with disability mainly on the ground of disability. There are other provisions contained in this section. Some of these include requiring employers or their agents to desist from discriminating against persons with disabilities in "(a) the job application procedure; (b) the terms and conditions of employment; (c) opportunity for promotion, advancement, transfer or training or to any other benefit associated with employment; (d) on-the-job training; (e) accommodation; (f) employee compensation".

And finally, in the areas of accommodation, safety and accessibility, section 3 states that it is unlawful for a person to discriminate against persons with disabilities by refusing them access to any public premises, facilities and services. Section 4 requires that public buildings are "constructed with the necessary accessibility aids such as lifts (where necessary), ramps and any other facility." Section 5 stipulates that "a road side-walk, pedestrian crossing and other facility made for public use shall be made accessible" for persons with disabilities. Furthermore, section 9 requires that "[in] parking lots, suitable spaces shall be properly marked and reserved" for persons with disabilities, whereas section 12 requires that persons with disabilities be given due and fair consideration in circumstances "where accommodation is being provided by schools for their students, employers for their employees, service providers for their customers, organisations for their members, government for the persons". 
With respect to children with disabilities, the Disabilities Act prohibits embarking on any activity that curtails the rights of children with disabilities whether in education or in other areas. In addition to guaranteeing their education, the Act in article Io(I) proscribes using children with disabilities to beg for alms. It states: "A person shall not employ, or use another person with disability in soliciting for alms".

The discussion of both the international and local legal instruments and documents of rights in general, and rights of person with disabilities in particular, gives us the context in which to be able to discuss a number of exclusionary and discriminatory practices and highlight how these constitute violations of the rights of person with disabilities. This discussion will be preceded by a brief examination of the socio-economic landscape in Nigeria and a highlight of disability figures in the country.

\section{Nigeria's socio-economic landscape}

With an estimated population of $2 \mathrm{I} 4$ million people, Nigeria is the most populous country in Africa (Central Intelligence Agency, n.d.). It consists of about 250 ethnic groups. Using the 2018 population estimate, the Central Intelligence Agency (n.d.) notes that the largest ethnic groups are the Hausa (30\%), Yoruba (I5.5\%) and Igbo (15.2\%). Other ethnic groups include Fulani (6\%), Tiv (2.4\%), Kanuri/Beriberi (2.4\%), Ibibio (I.8\%), Ijaw/Izon (I.8\%), and others (24.7\%) (Central Intelligence Agency, n.d.). As a relatively young democracy, the country is classified as an emerging market and a mixed economy (Nigeria's current democratic dispensation kicked off in May I999). The World Bank (2016) categorised Nigeria as a lower middle-income country. With its abundant supply of natural resources its economy is the second biggest in Africa. The Nigerian Stock Exchange is the second largest in Africa and its financial, legal, communications and transport sectors are relatively well-developed.

According to the 2014 Nigeria's Economic Report released by the World Bank (2014, July), Nigeria experienced in 2013 one of the world's highest economic growth rates, averaging $7.4 \%$ a month. But this has since contracted with the country presently being in a recession. Poverty remains very high with over half of the population living on less than a \$I (US) a day. The 20I4 figures released by Nigeria's National Bureau of Statistics puts the number of Nigerians living in "absolute poverty" at $54.7 \%$. One factor that has been suggested as contributing to the rise in poverty is the level of corruption in Nigeria. Transparency International's Corruption Perception Index covering the I99os and mid 2000 s consistently placed Nigeria among the ro most corrupt countries in the world. Its 2017 Corruption Perceptions Index places Nigeria I40 out of 180 countries, meaning that it ranks in the $27 \%$ percentile, that is a score of 27/100 (Transparency International 2017).

\section{Disabilities figures in Nigeria}

The 2006 National Census in Nigeria (which was conducted by the National Population Commission) puts the number of people with disabilities at 3,253,I69 (out of a national population figure of $140,431,790$ ). A breakdown of this figure shows that the total number of women and children with disabilities stand at I,544,4I 8 and I,002,062, respectively. This puts the total number of people with disabilities in 2006 at approximately $2.32 \%$ 
of the population (I40,43I,790). Of the $2.32 \%$ (i.e. those with disabilities), women with disabilities constitute I.I\% and children with disabilities $0.71 \%$ (Federal Republic of Nigeria Official Gazette, 2009; National Population Commission, 2010). These figures can be said to be conservative, that is, they do not seem to considerably represent the actual number and prevalence of disability in Nigeria. In addition, the total number of people with disabilities would have risen, given that the population of Nigeria has increased to about 2I4 million people (from the Central Intelligence Agency's 20I8 population estimate). So, if we keep in mind this estimate as well as take into account the WHO assessment that $15 \%$ of any given population has some form of disability (WHO, 2013) or even the point made by Mba (I977) and Abang (I99I) regarding the difficulties in achieving a reliable census for those with disabilities in Nigeria, then the total figure of people with disabilities should be around 32 million.

\section{Rights, discriminatory practices, and persons with disabilities}

In the next two subsections, the focus of the discussion on discriminatory practices and rights is going to be on practices that violate the rights of persons with disabilities in general (i.e. both adults and children with disabilities). This will be followed by two subsections; both of which pursue further the theme of the violations of rights and discriminatory practices against each of the categories of persons with disabilities. The first of the subsection will focus on adults with disabilities and the second on children with disabilities.

\section{Discriminatory practices and the rights to education and accessibility of persons with disabilities}

The discriminatory practices against persons with disabilities that will be examined here are in the areas of education and accessibility.

Persons with disabilities are generally discriminated against in the area of education in Nigeria. One way in which they are discriminated against is in the availability or lack thereof of financial resources and educational institutions to cater for their needs. Presently, there are not many educational institutions and inclusive schools that exist for persons with disabilities across the country. This lack of resources and educational institutions clearly impacts on the number of adults and children with disabilities who are unable to go to school. The Global Accessibility News (2016) reports that the United Nations Children's Fund estimates that there is an estimated Io million children that are out of school in Nigeria and of this number "more than $3 \mathrm{~m}$ of them are children with disabilities" (see also the Joint National Association of Persons with Disabilities, 2016). According to the Joint National Association of Persons with Disabilities (JONAPWD), the reason why these children are not in school is that the "school environments are not inclusive and accessible" to them. In the opinion of Deji Ademefun, the national programme manager for JONAPWD, this number constitutes an emergency and one that calls for major concern, since, according to him, these are children who deserve quality basic education in order to enjoy fulfilling lives (The Global Accessibility News, 2016). Of those who do find themselves in schools, they generally have difficulties accessing 
and obtaining government scholarships for their studies. This situation has led to a few protests. For example, in November 2009 students with disabilities and graduates staged peaceful protests in several Nigerian cities over what they considered unjustified discrimination against them by the government in the areas of employment and scholarships (Fatunde, 2009). Added to this is the issue of availability of resources and facilities for the few inclusive schools that are available for people with disabilities. Writing with regard to children with disabilities, Armstrong (20I4) notes: "A visit to one of the schools that have inclusive education for children with disability shows poor enrolment of pupils and also an inadequate number of teachers per student ratio. One of the teachers who spoke on condition of anonymity expressed frustration at the number of teachers available to teach children with special needs especially deaf pupils" (see also Adepoju \& Fabiyi, 2007; Ajuwon, 2008; JONAPWD, 2014 and 20I6; and Global Accessibility News, 20I6).

A further aspect to the problem of the availability of resources and facilities for inclusive schools is that of appropriate career development for children with disabilities who are enrolled in such schools. These schools are focused on vocational skills but as one of the special instructors tells Armstrong (2014), these children have dreams and ambition that go beyond just vocational education; they want "to learn liberal and other academic courses". Such divergence between what inclusive or special schools offer and what people with disabilities aspire to has been described by JONAPWD (2016) as arising because "special schools have been found to be socially dysfunctional and irrelevant to the total well-being of persons with disabilities". In addition to that, JONAPWD (2016) also states that because of the way these schools are organised and managed "they help reinforce negative social practices such as discrimination, segregation, low self-esteem and denial of the fundamental rights of children with disabilities".

When it comes to accessibility in education, schools and educational institutions notoriously fail to provide facilities that are inclusive of and accessible to persons with disabilities. This is the case whether the schools are inclusive/special or not. The impact of such exclusionary practice on persons with disabilities can be seen from the comments by Nkechi Nwokeke, a law student at the University of Ibadan, as reported in Next.com Nigeria (Adelaja, 200I). She mentions the effect on her studies of the lack of accommodation for wheelchair users in her university. According to her, she often has to depend on colleagues and friends to commute around and access various services. She describes this as frustrating and dehumanising and notes that the situation prevents her from going to the library to do research and to study sufficiently well for exams (Adelaja, 200I).

We see that provisions in the CRC and Disabilities Act pertaining to the right to education of persons with disabilities are violated by the above discriminatory and exclusionary practices. Both of these legal documents require that free education be provided for persons with disabilities. Whereas article 28 of the CRC speaks of the right to free and compulsory primary, secondary and vocational education, section 56 (I and 2) of the Disabilities Act talks of the right to free education at all levels in all public educational institutions. Yet, as we see above, about Io million children in Nigeria are estimated to be out of school with more than 3 million of them being children with disabilities. 
Discriminatory practices and the right of accessibility of public facilities of persons with disabilities

Public facilities refer to roads, buildings, parking lots and other infrastructure that are made available for public use. Persons with disabilities in Nigeria are discriminated against in the area of accessibility of public facilities. That is, their rights are violated in the broad area of facilities and accessibility with regard to roads, buildings and other physical infrastructures (see Ihedioha, 2015).

The rights to mobility and accessibility are recognised in the CRPD (section 20) and Disabilities Act (sections 3, 4, 5, 9, and I2). In the context of these provisions, consider the problem of the lack of facilities and accessibility in the general area of public and social life. There are practices that exclude accessibility aids in the construction and modification of public buildings, roads, and other facilities. Constructing these facilities or failing to modify existing facilities so as to accommodate and cater for the needs of people with disabilities is in clear violation of the rights to mobility and accessibility provisions in both the CRPD and Disabilities Act. These practices, it must be noted, are widespread across the country.

The absence of facilities and accessibility not only discriminates against persons with disabilities; it makes life difficult for them. Consider one example - the case of Lekan Ajayi, a wheelchair user, as reported by the University World News (Fatunde, 2009). Ajayi is unable to move around and has to rely on others to do the simple things in life like going to the bank. According to him, since the bank facilities are not accessible by wheelchair, he has to send friends to the bank whenever he needs to do any transaction. He says: "I don't have any privacy... The way things are designed in this society makes me feel bad" (Fatunde, 2009).

\section{Discriminatory practices and the right to work and employment of adults with disabilities}

Adults with disabilities are discriminated against in the area of work and employment. They are discriminated against when they are either overlooked in job selection or promotion or not given the due consideration that they deserve at work. So, take the example of David Okon who (as reported by Azu, 2002 and in Next.com Nigeria, 2009) was demoted from the position of a bank training manager to telephone operator because of his disabilities. Commenting on this case, Lanre Adebayor - a journalist with visual impairment and spokesman of "Club 2 - I2 of Nigeria", an association of people with disabilities based in Lagos State, Nigeria — notes: "the fact that you are deformed physically or mentally will be used against you even when you are qualified and apply like any other person. [An] employer will explain it in two ways; it will be difficult for you and we don't have the facilities for you" (Azu, 2002; Next.com Nigeria, 2009). He adds: "Nigeria is guilty of nonchalance to the plight of these individuals... a situation of being turned back from a job interview on account of being disabled is not just nor is it pleasant to be denied access to housing by landlords merely on account of being a disabled person" (Azu, 2002).

The discrimination against people with disabilities is not confined to the job application stage. It carries over to the employment process itself. Here are a few examples of some 
people with disabilities who were interviewed by Ihedioha (2015) concerning their experiences in the workplace. Their experiences show that, in many organisations, there is a moderately high degree of discrimination against people with disabilities.

(I) "My sister, before I got this job I applied to several companies because I made a first class in my B.Sc. Any organization that sees my CV will want to invite me for an interview, but once I get to the company they will tell me that they do not have job for people like me. Once, I was invited for an interview. When I got there, while we were waiting for the interview to commence, one of the managers of the company that passed and saw me with my walking stick entered his office and asked one of his staff to invite me to his office. He asked me of my mission and I told him I was invited for an interview. He told me that they do not employ people with clutches in their organization, that I should leave their environment. I pleaded to be considered but he refused. He further threatened to use the security men to forcefully take me out of the premises. I left and felt so humiliated, and was almost asking God questions about my life. (IDI, Male 48 Year)."

(2) "I have not also been promoted, whereas my colleagues who were employed about the same time have been receiving their promotion. I had to ask why; I was not given any reasonable answer for not promoting me. For conferences and seminars, I was told when I confronted my boss sometimes ago that it will cost them much sending people like me for a course. Again, I cannot access some of the offices in the work environment. Once, I tried climbing the one of our office complex I fell. Since then I have never tried it again. (IDI, Male, 52 Years)."

(3) "I had my challenge on the job. My leg was amputated and the institution refused giving me any form of compensation. I was given a walking stick and a prosthetic limb. I had this challenge when I was trying to protect some students from cult boys. In the process these boys shot my leg and that was how I had the challenge. (IDI, Male 35 Years)."

(4) "Sometimes ago I was harassed by a colleague of mine in the office, who made a mockery of my walking stick. Another one casually called me a one-legged person; even when I reported the matter to my Head of department nothing was done about that... Similarly, when I went to the canteen to eat, while we were on queue I pleaded with a staff to allow me stand in front of him so I could be attended to fast since I would not be able to stand for so long. He retorted and asked if he was the cause of my challenge. (IDI, Male, 42 Years)."

The study by Ihedioha (2015) highlights what she calls "the extent of limitation to access to employment for those who are unemployed; and career development for those already in the employment of these organizations". As the study shows, the social exclusion of people with disabilities in the workplace is widespread, a practice that impacts on the effective engagement of people with disabilities in work organisations. This problem she notes, transcends recruitment and placement to issues of accessibility of employees with disabilities given that most organisations lack "special facilities in buildings, materials and equipped vehicles to cater for these persons". 
When we reflect on the case of Okon, and those interviewed by Ihedioha and some provisions in the Disabilities Act, it is clear that the right to work and employment of persons with disabilities in Nigeria has been violated. In particular, sections 67 and 68 prohibit employers from engaging in any form of discrimination against persons with disabilities in the work environment.

\section{Rights and discriminatory practices against children with disabilities}

Because children with disabilities also fall under the category of persons with disabilities, the exclusionary and discriminatory practices that were discussed above viz-a-viz the violations of the rights of persons with disabilities also apply to them. However, given that there are certain exclusionary and discriminatory practices that directly target children with disabilities, it is proper to examine these separately. The example of discriminatory practice against children with disabilities that will be considered in this section has to do with their being employed or used to beg for alms.

Alms-soliciting by children with disabilities is facilitated partly because of the importance placed on deference for parental authority in Nigeria. The latter is understood to broadly include authority wielded not just by parents but also by surrogates or guardians. For purposes of this paper we shall be using the term parent(s) to also include surrogate(s) or guardian(s).

The cultural value or role of parental deference means that a child is not expected to resent the authority of his or her parents; a child who does that is most often criticised and sometimes punished. She or he may be spanked, denied some necessities, locked up in a room, grounded for days or weeks, or sent away from home (Etieyibo \& Omiegbe, 2016). Given the authority that parents wield over their children, it is generally easy for them to use and engage children with disabilities as alms-beggars. The point is that whereas some child beggars follow their parents' authority and go into alms-soliciting because of the cultural role of parental deference, others obey their parents simply out of fear of being punished (Omiegbe, I995).

Many parents do not see anything problematic and wrong with using their children with disabilities as alms-beggars. In fact, some compare it to child street-trading. The argument some often make is that if parents could reap economic reward by using their children as street traders, there is no reason why they could not use their children with disabilities to "earn" money for the family. Of course, the practice of employing children to solicit for alms has to be understood in the context of the broader practice of almssoliciting, in general, and children alms-soliciting, in particular (see Dunapo, 2002). In this context, economic and other reasons such as religious can then be said to drive the practice of alms-soliciting.

Alms-soliciting brings monetary and material benefits and thus many parents see it as profitable to send their children with disabilities out on the streets to beg for alms (Omiegbe, 1995). However, to reduce all alms-soliciting in Nigeria to the economic aspect is to present a simplistic analysis of the culture and practice of alms-soliciting, as it discounts other (non-economic) reasons for alms-soliciting. According to Ozoji (I99I), there is a religious dimension to alms-soliciting in Nigeria as well. With regard to this 
dimension, parents of children with disabilities see the practice as one way of discharging their religious obligations, although economic considerations may be lurking in the background. A good example of alms-soliciting that has a religious dimension is the age-old Almajiri system of Islamic scholarship and religious practice in northern Nigeria (Yakasai, I990; Amupitan, 200I; Dunapo, 2002; Yusha'u, Tsafe et al., 2013). This is an ancient practice whereby poor families from many rural areas across West Africa send their children (with or without disabilities) to a network of Islamic boarding schools in the cities of northern Nigeria. The problem is that once in the schools, the Almajiri receive little education and money and must - out of necessity - beg to survive (Purefoy, 20I0; see Obaro, 2016).

On either the economic or religious dimensions of alms-soliciting, employing or using children with disabilities as alms-beggars violates certain rights the children are supposed to enjoy. Some of the rights violated are those contained in the CRC in articles 23,28 and 32 . The rights are expressed in these articles as follows: article 23 (the right to enjoy a full and decent life, in conditions that ensure dignity, promote self-reliance and facilitate the child's active participation in the community); article 28 (the child's right to free and compulsory primary education, to secondary and vocational education and the prevention of drop out); and article 32 (the right to the protection of the child from work that interferes with education). As we have seen, many children with disabilities who go out in the streets to solicit for alms do not go to school and thus are prevented from enjoying these rights.

Also, article Io(I) of the Disabilities Act states that "a person shall not employ, or use another person with disability in soliciting for alms". But is this not exactly what parents do when they use children with disabilities to solicit for alms? Often these children are put in dangerous situations. As the Guardian newspaper reports, in Lagos alone about roo childbeggars between the ages of 6 and $\mathrm{I} 2$ with different forms of disabilities are killed in highways by vehicles and motorbikes every year while soliciting for alms (Okpala, 200I). It also reports that a number of children are kidnapped for rituals purposes (Okpala, 200I). Whether for economic or religious reasons it is therefore right to say that parents who employ their children with disabilities as alms-solicitors are self-centred. Indeed, they care more about the gains that their children with disabilities can help procure for them from alms-soliciting rather than what is right or in their children's best interest. In their view, utility is best served to send their children with disabilities to beg for alms rather than, for example, to enrol them in schools or educational institutions where they can acquire knowledge or skills that will be useful to them in life. The point simpliciter is that they care less about their children's future and see them as "objects" and mere means to be manipulated and exploited for their own personal interests and benefits.

Using children with disabilities to solicit for alms violates their rights as has been shown above. There is another way also in which the employment of children with disabilities for alms begging can be said to violate their rights. This is in the area of child workers. Child labour has attracted both domestic and international human rights concern. Ibhawoh (I999) noted that child labour is increasingly being recognised as one of the most widespread forms of violation of the rights of the child. There are explicit provisions 
in various international and domestic conventions and laws that forbid child labour and exploitation (Ekwowusi, 2004; Obizeke, I988).

The CRC sets the standard for how children should be treated around the world. Article 32 of the Convention enjoins member states to take appropriate measures to recognise the right of the child, to protect children from economic exploitation and from performing any work that is likely to be hazardous to them or interfere with their moral, physical, mental, spiritual or social development. The African Charter on the Rights and Welfare of the Child has similar provisions for the rights and welfare of the child (Africa, African Union Charter, Article I5). Nigeria is a party to both the CRC and the African Charter on the Rights and Welfare of the Child and is thus obligated to follow through on recognising and protecting the interests and rights of children (both those without disabilities and those with disabilities).

In addition to these documents, there are domestic laws in Nigeria which cater for the welfare of children in the country. The 1999 Nigeria Labour Act for instance, has elaborate provisions against the employment of young persons below a certain age and in certain jobs (Nigeria, Labour Act of 1999, Part III, Sections 59-64). Yet, children with disabilities are increasingly being employed to solicit for alms in Nigeria. They are found in many main streets in Nigeria sometimes accompanied by their parents (Okpala, 200I: 2I). Article ro(2) of the Disabilities Act states that anyone who employs a person with disability "is liable on conviction to 6 months imprisonment or a fine of NIoo, ooo" (\$275 US / €23I) or both. We are neither aware of the prosecution of any parent or person employing children with disabilities to beg for alms nor any awareness program meant to sensitize citizens or help them appreciate the importance of education for children with disabilities and not using them to beg for alms.

\section{One worry: human rights as Western discourse or invention}

The notion of human rights has been used throughout the discussion in this paper. Indeed, reference has been made to particular rights in international legal instruments and documents to ground the argument that certain exclusionary and discriminatory practices violate the rights of people with disabilities in Nigeria. However, someone may query the use of human rights language or the nature and essence of rights and human rights. Specifically, the person might point to the discussion in this paper as saying nothing about the ongoing debate regarding human rights as a western discourse or "invention." There are two things that can be said to this.

First, anyone familiar with human rights discourse and its history will know that the jury is still out with regard to whether human rights are relative to context and culture or whether they are a Western invention. That is, there is no agreement among scholars concerning the issue as to whether or not human rights are a Western discourse or invention. For some historical and current discussions on human rights, its nature and whether it is universal see An-na'im \& Deng (I990); Allsobrook (20I8); Baet (200I); Cobbah (I987); Donnelly (I982, I984 \& 2007); Olowu (2009); Oyowe (20I3 \& 20I4); Pollis \& Schwab (I979 \& I980); Preis, I996; Weinstein (I976); Ishay (2004); Khushalani (I983); O’Sullivan (2000); Peetush (2003); Penna \& Campbell (I998); Perry (I997); 
Talbott (2005); El-Obaid \& Appiagyei-Atua (I996); Manglapus (I978); Legesse (I980); Halliday (1995); Beitz (200I); Busia (I994).

Second, the issue of whether human rights should be taken as some western invention is one that could be theoretically and intellectually productive. However, the issue may be said to be moot or unfruitful in the context of discussions about human rights which implicate governments and where policies or policy making are concerned. The point is this. Since the rise of organisations such as the United Nations on the global stage, many governments have signed up to legal documents (treaties, conventions, protocols, etc.) such as those concerning human rights. Therefore, even if it is established theoretically and intellectually that human rights are invented by the West, the fact that at the levels of government, inter-governmental and policy making human rights are accepted, any talk of the language of human rights as a Western invention becomes moot and, if anything, not very productive. This point becomes poignant if one considers that the concern in this paper is about how discussions of human rights, in particular rights in connection with persons with disabilities, implicate governments at the policy making level. So, given that human rights already form part and parcel of the language of many governments - entrenched in most constitutions - the important issue, for us (in the context of the violations of the rights of persons with disabilities) then should not be that of interrogating the origin or invention of human rights. Rather, our task should be about investigating how well these governments are doing in terms of the realisation of human rights (which they have already accepted without reservations) or meeting their obligations to their citizens. This is not to say that investigating or debating about whether human rights have their origin from the West is not important. It is. The point, however is that such a focus can be taken up in a different paper and it is not one that this paper is set out to do.

\section{Some recommendations}

This section examines a number of recommendations, which are germane in addressing some of the issues on disabilities that have been discussed in the paper. For some additional discussion recommendations see Etieyibo and Omiegbe (2017).

\section{Advocacy and education}

Given the prevalence of negative perceptions of disability in Nigeria and the relationship between this, and discriminatory practices against people with disabilities, it will be helpful in addressing these practices for both the government and non-governmental organisations (NGOs) to embark on advocacy programs aimed at educating the public. Such advocacy efforts may take the form of the government and NGOs working with communities to eradicate customs and practices that discriminate against people with disabilities in communities where they are most visibly expressed. The advocacy can also take other forms: from public presentations and advertisement about the rights of people with disabilities to the inclusion of topics on disability in subjects that are taught in schools. The aim here is for the government and NGOs to help foster among members of the public an attitude of respect for the rights of persons with disabilities. 


\section{Legal protection of people with disabilities}

In order to protect the rights of people with disabilities a number of things need to be done. First, it is essential that there are laws that prohibit against the violations of the rights of persons with disabilities - both at the Federal and State levels. To this extent, it will be important not just for the President to sign into law the Disability Act but for the various State governments to pass complementary Acts at the State level. In addition to this, policy-makers and law-enforcers must be trained not just on the positive perception and attitudes toward disability but also on ways in which they can perform their jobs most effectively. Furthermore, the prosecution of violators of the rights of people with disabilities must not only be given a priority but must also be swift. This might call for the establishment of special courts, which will legally be empowered to handle cases that have to do with discrimination against people with disabilities.

\section{Research and statistics on disabilities in Nigeria}

One of the difficulties that this paper was confronted with is the paucity of published/ empirical work on disabilities in Nigeria. It will be helpful for further discussion on disabilities if more research (particularly, empirical research) is conducted. In addition, there is the problem of accurate and up to date statistics on disabilities. The government's record on disabilities is very poor and the figures that are available in the books are not very current. Both of these problems (scarcity of research and accurate statistics on disabilities) make it difficult to draw meaningful and reliable conclusions on disability in Nigeria, its various dimensions as well as to discuss effects and implications of policies in respect of person with disabilities.

\section{Conclusion}

The main objective in this paper is to examine some legal frameworks and instruments in the context of exclusionary and discriminatory practices against persons with disabilities in Nigeria. These practices are in the areas of education and accessibility with regard to persons with disabilities (that is, adults and children with disabilities), work and employment in respect of adults with disabilities, and the employment or using of children with disabilities in alms-soliciting. A case was made that these practices overstep the legal frameworks and instruments in the sense that they violate the rights of persons (adults and children) with disabilities.

There are other practices that have not been discussed here which may also violate the rights of persons with disabilities. As for the practices that we have examined, there is something that is distinctive about them. Not only do they constitute one form of violation of the rights of persons with disabilities, they also fail to treat persons with disabilities as full humans. By failing to accord them full humanity, the practices treat persons with disabilities as mere instruments and undermine the norm of social justice (see Etieyibo 2020 for discussion about how exclusionary and discriminatory practices implicate issues of social justice). By this, we mean that the practices make a demarcation about humanity along a morally arbitrary line or simply, they single out persons with disabilities for prejudicial treatment, discount their value, do not represent them as equal 
members of society, are disrespectful to them, and consequently, block and impede their effective flourishing as equal citizens.

\section{References}

Abberley, P. (1987). The concept of oppression and the development of a social model of disability. Disability, Handicap \& Society, 2(I): 5-I9.

Abang, Theresa B. (I99I). Educating mentally retarded and gifted children in Nigeria. Jos, Nigeria: Organisation for Children with Special Needs.

Adelaja, A. (200I). Providing equal opportunities for persons with disabilities. Next.com Nigeria. 24 May 2011.

Adepoju, A. \& Fabiyi A. (2007). Universal Basic Education in Nigeria: Challenges and Prospects. http://uaps2007.princeton.edu/abstracts/70830

Union for African Population Studies, Fifth African Population Conference, Arusha, Tanzania, IO-I4 December, 2007 (Accessed 8 September, 2017).

Africa. (1986). African Union Charter (or African (Banjul) Charter on Human and Peoples' Rights).

Ajomo, M.A. \& Olasaneye, B. (eds.). (1993). Individual Rights under the 1989 Constitution. Lagos: Nigerian Institute of Advanced Legal Studies.

Ajuwon, Paul M. (2008). Inclusive education for students with disabilities in Nigeria: benefits, challenges and policy implications. International Journal of Special Education, November 23(3):II-I6.

Allsobrook, C. (2018). Universal human rights from an African social contract. In Edwin Etieyibo (ed.), Perspectives in Social Contract Theory. Washington: Council for Research and Values in Philosophy.

Amupitan, O. (2001). Farewell to alms-begging. The Nigerian Comet, I6 February.

An-na'im A. \& Deng F. (eds.). (I990). Human Rights in Africa: Cross Cultural Perspectives. New York: Brookings Institution Press.

Armstrong, T. (20I4). Inclusive education and challenges facing people with disability. Radio Nigeria, http://www.radionigerialagos.com/index.php/news/40-inclusive-education-and-challengesfacing-people-with-disability (Accessed 6 September, 2017).

Azu, M. (2002). Job placement. Daily Times, 2I June.

Baba-Ochankpa, R. (2010). Life is no picnic for disabled Nigerians. Next.com Nigeria, 4 August, n.p.

Baet, A. (200I). History of human rights. International Encyclopedia of the Social \& Behavioral Sciences, 70I27018.

Barnes, C. (199I). Disabled people and discrimination in Britain: the case for anti-discrimination legislation. London: Hurst \& Co.

Barton, L. (1993). The struggle for citizenship: the case of disabled people. Disability, Handicap \& Society, $8(3): 235-248$.

Beitz, Charles R. (200I). Human rights as a common concern. American Political Science Review 95 (2):269282.

Billings, Jenny R. et.al. (2009). Privacy and dignity in continence care project phase 2. Project report. Canterbury: Centre for Health Services Studies.

Busia, Nana Kusi Appea Jr. (1994). The status of human rights in pre-Colonial Africa: Implications for contemporary practices. In McCarthy-Arnolds, E, Penna, D. \& Cruz Sobrepena, D. (eds.), Africa, Human Rights, and the Global System: The Political Economy of Human Rights in a Changing World, pp. 225-250. Westport: Greenwood Press.

Central Intelligence Agency (n.d). (2020). The World Fact Book https:/www.cia.gov/library/publications/ the-world-factbook/geos/print_ni.html (Accessed I2 March, 2020).

Centre for Health Services Studies. (2009). Privacy and Dignity in Continence Care, I6 February 2009, pp.I-45. 
Charlton, J. (1998). Nothing about us Without us: Disability, Oppression and Empowerment. Berkeley, CA: University of California Press.

Cobbah, J. A. (1987). African values and the human rights debate: An African perspective. Human Rights Quarterly, 9(3): 309-331.

Cranston, M. (1980). Human rights: old and new. In Shridath.S. Ramphal (ed.), Political Theory and the Right of Man, pp.58-63. London: MacMillan.

Donnelly, J. (1984). Cultural relativism and universal human rights. Human Rights Quarterly, 6:400-4I9.

Donnelly J. (2007). The relative universality of human rights. Human Rights Quarterly, 29:28I-306.

Dunapo, O.S. (2002). Causative and sustaining factors to street hawking in Nigeria: Implications for all development. In Okonkwo, R.U. \& Okoye, R.O. (eds.), The Learning Environment of the Nigeria Child, pp. 36-49. Awka: NISEP.

Ekwowusi S. (2004). Rights of the child. Thisday, I6 June 2004.

El-Obaid, A. \& Appiagyei-Atua, K. (1996). Human rights in Africa: A new perspective on linking the past to the present. McGill Law Journal, 4I:8Ig-854.

Etieyibo, E. (2020). Social justice and persons with disabilities in Nigeria. In Etieyibo, E., Katsaura, O. \& Musemwa, M. (eds.), Africa's Radicalisms and Conservatisms I: Politics, Poverty, Marginalisation and Education. Leiden: Brill.

Etieyibo, E. \& Omiegbe, O. (20I6). Religion, culture, discrimination against persons with disabilities in Nigeria. African Journal of Disability, 5(I):I-6.

Etieyibo, E. \& Omiegbe, O. (2017). Disabilities in Nigeria: Attitudes, Reactions, and Remediation. Lanham, MD: Hamilton Books.

Eze, O.C. (1984). Human rights defined. In Human Rights in Africa: Some Selected Problems. Lagos: Nigerian Institute of International Affairs and Macmillan Publishers.

Fagan, A. (2010). Human rights. Internet Encyclopaedia of Philosophy http://www.iep.utm.edu/hum-rts/ (Accessed 28 January 2015).

Fatunde, T. (2009). Disabled protest at discrimination. University World News. I5 November 2009; http://www.universityworldnews.com/article.php?story=20091113141506713, (Accessed on ro September 2013).

Global Accessibility News. (2016). Three million children with disabilities out of school in Nigeria. http://globalaccessibilitynews.com/2016/07/I6/three-million-children-with-disabilities-out-ofschool-in-nigeria/ (Accessed on 8 September 2017).

Hahn, H. (I986). Public support for rehabilitation in programs: The analysis of US disability policy. Disability, Handicap \& Society, I(2):I2I-I38.

Halliday, F. (I995). Relativism and universalism in human rights: The case of the Islamic Middle East. Political Studies, 43:152-I67.

Ibhawoh B. (1999). Between Culture and Constitution: the Cultural Legitimacy of Human Rights. Copenhagen: Danish Centre for Human Rights.

Ihedioha, E. (2015). Environmental barriers and job placement of the physically challenged in organizations in rivers state, Nigeria. Global Journal of Arts Humanities and Social Sciences, April 3(4):I-I3.

Ishay, M. (2004). The History of Human Rights: From Ancient Times to the Globalization Era. Berkeley, CA: University of California Press.

Joint National Association of Persons with Disabilities. (2016). Brief on the inclusive basic education project for children with disabilities in Nigeria. http://www.jonapwd.org/Brief\%20About\%20 The\%20INCLUSIVE\%20BASIC\%20EDUCATION\%20FOR\%20CHILDREN\%20WITH\%20 DISABILITIES\%20PROJECT.pdf (Accessed on 5 2I September 2017). 
Joint National Association of Persons with Disabilities. (2014). Inclusive and accessible basic education for children with disabilities in Nigeria: The role of federal and state ministries of education. http://www.jonapwd.org/Factsheet\%2oinclusive\%20Education.pdf (Accessed on I5 September 2017).

Khushalani, Y. (1983). Human rights in Asia and Africa. Human Rights Law Journal, 4(4):403-442.

Legesse, A. (I980). Human rights in African political culture. In Thompson, K. (ed.), The Moral Imperatives of Human Rights: A World Survey, pp.I25-I34. Lanham, MD: University Press of America.

Manglapus, R. (1978). Human rights are not a western discovery. Worldview 4:4-6

Mba, P.O. (1977). National policy on special education: some thought on the new national policy on education of the Nigerian Council of Adult Education. In Nigerian Council of Adult Education, pp.128134. NNCAE: Ibadan.

Next.com Nigeria. (2009). The lost ones. Io December 2009.

Nickel, J. (1987). Making Sense of Human Rights: Philosophical Reflections on the Universal Declaration of Human Rights. Berkeley, CA: University of California Press.

Nigeria. (1999a). Constitution of the Federal Republic of Nigeria.

Nigeria. (I999b). Labour Act of 1999.

Nigeria. (2009/20II/2016). Discrimination Against Persons with Disabilities (Prohibition) 2009 Act.

Nigeria. (2009). Federal Republic of Nigeria Official Gazette, 2 February 2009, Abuja, 2:96.

Nigeria. (2010). National Population Commission, Census Priority Table: 2006 Population Distribution by, Sex and Class Size of Household State and Local Government Area, Table HH (ADD I), vol IX, April.

Nigeria, National Bureau of Statistics. (2016). http://www.nigerianstat.gov.ng/ (Accessed on 27 October 2016).

Obaro, H. (2016). The Almajiri: Abused, neglected. The Guardian, 29 February, https://guardian.ng/ news/the-almajiri-abused-neglected/ (Accessed on 9 September 24, 2017).

Obizeke D.S. (1988). Agricultural labour in Nigeria: A case study of Anambra State. In Child Labour in Africa. 44 Proceedings of the First International Workshop on Child Abuse in Africa, 27 April - 2 May.

Okpala E. (200I). Death on highways. The Guardian, 20 May 200I, p2I.

Oliver, M. (1990). The Politics of Disablement. MacMillan: London.

Olowu, D. (2009). An Integrative Rights-based Approach to Human Development in Africa. Pretoria: Pretoria University Law Press.

Omiegbe, O. (1995). The handicapped and begging. Paper presented at the Fifth National Conference at the Department of Special Education, University of Ibadan, Ibadan. 28-3I August.

O'Sullivan, D. (2000). Is the declaration of human rights universal? Journal of Human Rights, 4 (I):25-53.

Oyowe, A. (2014). An African conception of human rights? Comments on the challenges of relativism. Human Rights Review, 15(3):329-347.

Oyowe, A. (2013). Strange bedfellows: Rethinking Ubuntu and human rights in South Africa. African Human Rights Law Journal, I3: 103-I24.

Ozoji, E.D. (199I). Psychology of Attitudes Towards the Disabled: The Nigerian Perspective. Jos: University of Jos.

Peetush, A. (2003). Cultural diversity, non-western communities, and human rights. The Philosophical Forum, 34 (I):I-I9.

Penna, D. \& Campbell, P. (I998). Human rights and culture: Beyond universality and relativism. Third World Quarterly, I9 (I):7-27.

Perry, M. (1997). Are human rights universal? The relativist challenge and related matters. Human Rights Quarterly, I9 (3):46I-509.

Pollis, A. \& Schwab, P. (1979). Human Rights: Cultural and Ideological Perspectives. New York: Praeger Publishers. 
Pollis, A. \& Schwab, P. (I980). Human rights: A Western construct with limited applicability. In Pollis, A. \& Schwab, P. (eds.), Human Rights: Cultural and Ideological Perspectives, pp.I-I8. New York: Praeger.

Preis, A-B. (1996). Human rights as cultural practice: An anthropological critique. Human Rights Quarterly, I8(2):286-3I5.

Pritchard, D. (1963). Education and the Handicapped 1760-1960. London: Routledge and Kegan Paul.

Purefoy, C. (2010). Nigeria's Almajiri children learning a life of poverty and violence. CNN, 8 January, n.p.

Talbott, W. (2005). Which Rights Should Be Universal? New York: Oxford University Press.

Teaching for Diversity and Social Justice. (2007). Perspectives on the historical treatment of people with disabilities, 2nd edn., Routledge, http://www.life.arizona.edu/residentassistants/programming/ diversity/Ability/ Ability.Hist.pdf (Accessed on 8 December 20II).

Transparency International. (2017). Corruption Perceptions Index 2017 (Country/Territory: Nigeria, https://www.transparency.org/country/NGA (Accessed on 4 May 2018).

United Kingdom. (1995). Disability and Discrimination Act 1995.

United Nations. (1948). Universal Declaration of Human Rights.

United Nations. (1966a). International Convention on Civil and Political Rights.

United Nations. (1966b). International Covenant on Economic, Social and Cultural Rights.

United Nations. (1989). Convention on the Rights of the Child.

United Nations. (2006a). Convention on the Rights of Persons with Disabilities.

United Nations. (2006b). Convention and Optional Protocol Signatures and Ratifications.

Weinstein, W. (1976). Africa's approach to human rights at the United Nations. Issue: A Quarterly Journal of Opinion, 6(4):I4-2I.

World Bank. (2014). Nigeria's Economic Report, World Bank, 2014 Nigeria's Economic Report http:// documents.worldbank.org/curated/en/337181468100I45688/Nigeria-economic-report (Accessed 30 October 20I6).

World Bank. (2016). List of economies. www.worldbank.org (Accessed on 3I October 2016).

World Health Organisation. (2020). Disabilities. Available at https://www.who.int/topics/disabilities/en/ (Accessed on 3 June 2020).

World Health Organisation. (20II). Word Report on Disability. Available at https://www.who.int/disabilities/world_report/201I/report.pdf. (Accessed on 3 June 2020).

World Health Organisation. (2018a). Disability and Health. Available at https://www.who.int/news-room/fact-sheets/detail/disability-and-health. (Accessed on 3 June 2020).

World Health Organisation. (2018b). International Classification of Functioning, Disability and Health (ICF). Available at https://www.who.int/classifications/icf/en/. (Accessed on 3 June 2020).

Yakasai, A. (1990). Begging as an aspect of child abuse negligence. In Rights of the Nigerian child, Proceedings of the Third Biennial Conference on the Rights of the Nigerian Child, ANPPCAN Kwara State Branch. Ilorin: Kwara State Branch: Kwara State Branch Government and UNICEF.

Yusha'u, M.A., Tsafe, A.K., Babangida, S.I. \& Lawal, N.I. (2003). Problems and prospects of integrated Almajiri education in northern Nigeria. Scientific Journal of Pure and Applied Sciences, 2(3), I25-I34. 